\title{
INFLUENCE OF WILDFIRE AND FIRE SUPPRESSION BY SEAWATER ON SOIL PROPERTIES
}

\author{
BOGUNOVIC, I. $^{1 *}-$ KISIC, $^{1}{ }^{1}-$ JURISIC, A. ${ }^{1}$ \\ ${ }^{I}$ Department of General Agronomy, Faculty of Agriculture, University of Zagreb \\ Svetosimunska 25, 10000 Zagreb, Croatia \\ (phone: +385-1-239-3815; fax: +385-1-239-3981) \\ *Corresponding author \\ e-mail: ibogunovic@agr.hr; phone: +385-1-239-3815; fax: +385-1-239-3981
}

(Received $25^{\text {th }}$ Apr 2015; accepted $28^{\text {th }}$ Sept 2015)

\begin{abstract}
During the last decades rapid climate changes have occurred and through frequent fires they have strongly affected the landscape. Wildfires directly influence on soil properties and generally increasing availability of nutrients. Due to the lack of multiple sources of freshwater, most fires in Dalmatia are being extinguished by seawater, which directly affects soil properties. During October 2012 soil samples $(0-5 \mathrm{~cm})$ were collected at four different locations from a burned and unburned plots in order to observe the impacts of fire on soil properties. Samples were collected 14 and 2 months after the wildfires occurred in 2011 and 2012, depending on the location. This paper analyzes the effects of wildfire and seawater used for fire suppression on soil chemical properties. The results showed significant differences between burned and unburned soil plots for $\mathrm{pH}$, plant available phosphorus $(\mathrm{P})$ and potassium $(\mathrm{K})$, total carbon and total nitrogen. Differences between electrical conductivity (EC), $\mathrm{F}^{-}, \mathrm{Cl}^{-}, \mathrm{SO}_{4}^{2-}, \mathrm{Na}^{+}$, $\mathrm{Mg}^{2+}$ and $\mathrm{Ca}^{2+}$ in burned and unburned plots also exist. Burned plots contain higher average values of $\mathrm{K}$, $\mathrm{P}, \mathrm{EC}$ and all water-extractable elements. Soil $\mathrm{pH}$ conditions after wildfire favors the solubility of some elements presented in this paper. These investigated parameters are under the direct influence of fire intensity and seawater on the ground. This study is useful for understanding changes in soil chemistry after fire and seawater application.
\end{abstract}

Keywords: Dalmatian region, seawater, soil properties, wildfire

\section{Introduction}

Fire is great disturbances in the ecosystems, but it is also an important ecological element (Pereira et al., 2012), fundamental for the landscape sustainability. In forest system wildfire can alter vegetation composition and even promote tree regeneration (Martínez-Sánchez et al., 1999; Cammeraat and Imeson, 1999). Fire was used in landscape management, and there are ecosystems like Mediterranean whose functions cannot be understood without fire (Pereira et al., 2010a; Mataix-Solera and Cerdà 2009). In the period of 1998-2008, out of all the forest fires in Croatia 31.7\% were recorded in Dalmatia region (Croatian Mediterranean area that consists of 4 Croatian counties). In burned forest areas of Croatia, Dalmatia participates with as much as $64.3 \%$, and for the most part $(50.2 \%)$ these areas are overlain by Coppice Forests, shrubs, garrigues and thickets (Mamut, 2011). Wildfires are natural events, but the increased recurrence of wildfires in recent decades has an obvious anthropogenic component (Rovira et al., 2012).

Following wildfire, ash commonly covers the soil surface for some time until it is removed by wind or water erosion. Fires reduce soil organic matter on the surface and leave the soil unprotected from erosion which leads to very fast loss of ash material from the surface (Cerdà and Doerr, 2008; Pereira et al., 2013), especially if the burned areas are at higher inclinations. The erosion moves ash material which affects chemical 
properties of soil. This layer is a key factor for soil chemistry after the fire and can be many centimeters thick and can affect soil erosion (Cerdà, 1998a) and runoff generation processes and rates (Cerdà, 1998b).

Chemical composition of forest fire ash can be very variable and depends on various factors (Dlapa et al., 2013), like burning temperature, type of plant species, part of plant combusted, time of exposure to heat, fuel density and arrangement, and other factors affecting combustion conditions (Liodakis et al., 2005; Pereira et al., 2011). Dominant elements in wood ash are calcium $(\mathrm{Ca})$, potassium $(\mathrm{K})$, magnesium $(\mathrm{Mg})$, silicon $(\mathrm{Si})$, manganese $(\mathrm{Mn})$, aluminium $(\mathrm{Al})$, phosphorus $(\mathrm{P})$, sulphur $(\mathrm{S})$, iron $(\mathrm{Fe})$, sodium $(\mathrm{Na})$ and zinc (Zn) (Etiegni and Campbell, 1991; Liodakis et al., 2007). Many researchers (Andreu et al., 1996; Monleon et al., 1997; Hatten et al., 2005; Certini et al., 2011; Yinghua et al., 2012; Rovira et al., 2012; Bogunovic et al., 2014) have investigated wildfire and their impact on biological and chemical soil characteristics. Some of them have determined the reduction of total carbon (TC) (Certini et al., 2011) and $\mathrm{N}$ in soil (Rovira et al., 2012), low $\mathrm{K}$ variations and similar $\mathrm{pH}$ and $\mathrm{P}$ content one year after the fire (Andreu et al., 1996), while others (Yinghua et al., 2012; Bogunovic et al., 2014) observed higher soil $\mathrm{pH}$ and $\mathrm{P}$ content in burned soils 15 months post fire. Some studies (Hatten et al., 2005) recorded negligible difference in soil properties between burned and unburned areas, while Monleon et al. (1997) noted that 12 years post fire TC and inorganic $\mathrm{N}$ content were returned to unburned levels.

A serious problem of fire suppression in Dalmatia is the access to fresh water. Fire brigades use fresh water in wildfire ground suppression, but in many cases due to the inaccessible terrain air forces use seawater for wildfire suppression. According to chemical composition, the seawater is unsaturated homogeneous solution composed of water as a solvent (96.5\%), dissolved salts (3.5\%), small amounts of particulate matter, dissolved gases and organic ingredients. More than ninety chemical elements are found in seawater, and six major elements dominate: $\mathrm{Na}^{+}, \mathrm{Mg}^{2+}, \mathrm{Ca}^{2+}, \mathrm{K}^{+}$, chlorine $\left(\mathrm{Cl}^{-}\right)$and $\mathrm{S}$, while $\mathrm{Na}^{+}$and $\mathrm{Cl}^{-}$account for more than $85 \%$ of the total (Martinac, 2010). These elements from seawater and ash material are leached into run-off and into the soil profile and may have impacts on surface soil chemistry.

There are several types of soil salinity and all refer to areas where soils contain high levels of salts (e.g. $\mathrm{Na}^{+}, \mathrm{Ca}^{2+}, \mathrm{Mg}^{2+}, \mathrm{HCO}_{3}{ }^{-}, \mathrm{Cl}^{-}$and $\mathrm{SO}_{4}{ }^{2-}$ ) that can affect plant productivity and soil organisms (Navarro-Pedreño et al., 1997). In this study the saline water application is not a result of arid environment or irrigation, since the source of salts is the seawater used for fire suppression. Seawater affects the natural ecosystem in the form of water and salt stress. Accumulation of dispersive cations, such as $\mathrm{Na}^{+}$in soil solution and the exchange phase $\left(\mathrm{K}^{+}, \mathrm{Mg}^{2+}, \mathrm{Ca}^{2+}\right)$ affect the physical properties of soil, such as structural stability, hydraulic conductivity, infiltration rate and erosivity (Juan et al., 2011). A plant in a drying, saline soil is exposed to increased levels of both water stress and osmotic stress, because the matric potential and the osmotic potential decrease simultaneously with decreasing soil moisture (Johnson, 1992). At the same time, the seawater undoubtedly affects burned soil. Researchers have investigated the effects of saline water on crops and soil (Richards, 1992; Sheng et al., 1997; Katerji et al., 2003; Ahmed et al., 2010; Chen et al., 2010; Ben Ahmed et al., 2012) but there is lack of studies of impact of seawater on fire-affected forest soils in the environmental conditions of Dalmatia, a part of Mediterranean. 
The aim of this paper is study the effect of seawater on burned soil properties, TC, total nitrogen (TN), $\mathrm{K}$ and $\mathrm{P}, \mathrm{EC}$ and water extractable ions $\left(\mathrm{F}^{-}, \mathrm{Cl}^{-}, \mathrm{SO}_{4}{ }^{2-}, \mathrm{Na}^{+}, \mathrm{Mg}^{2+}\right.$, $\left.\mathrm{Ca}^{2+}\right)$ after a wildfire in Dalmatia, Croatia.

\section{Material and Methods}

\section{Site Characteristics}

The study area is located in island Korcula and Peljesac peninsula in southern Dalmatia: Smokvica (42 $55^{\prime}$ N, 16 $6^{\circ} 54^{\prime}$ E, 97 m.a.s.1.), Blato $\left(42^{\circ} 56^{\prime} \mathrm{N}, 16^{\circ} 50^{\prime} \mathrm{E}, 185\right.$ m.a.s.l.), Panjika ( $42^{\circ} 51^{\prime} \mathrm{N}, 17^{\circ} 30^{\prime} \mathrm{E}, 305$ m.a.s.l.), Ponikve (42 $50^{\prime} \mathrm{N}, 17^{\circ} 37^{\prime} \mathrm{E}, 240$ m.a.s.l.). All four areas are in similar ecosystems with a Mediterranean climate characterized by long, dry and hot summers and mild and humid winters. Air temperatures are relatively high throughout the year (mean annual air temperature is $11.2^{\circ} \mathrm{C}$ ), and only during January and February temperatures are below $10^{\circ} \mathrm{C}$. Average minimum month temperature is $9.8{ }^{\circ} \mathrm{C}$ in January and average maximum month temperature is $26.9{ }^{\circ} \mathrm{C}$ in July (Meteorological and hydrological institute of Croatia, period 1961 - 1990). Average annual rainfall is $1300 \mathrm{~mm}$ and increases from the coastal area to the interior of the island, and from lower to higher altitudes. Average annual number of sunny hours amounts to over 2500 at some locations. The area is covered with Mediterranean flora and sometimes pine trees. All wildfires on investigated locations were supressed from air with seawater, while Table 1 shows detailed information on the characteristics of individual sampling locations.

Table 1. Site characteristics for burned and unburned sampling locations on Chromic cambisols. B-burned; C-unburned

\begin{tabular}{|c|c|c|c|c|c|c|}
\hline $\begin{array}{l}\text { Sample } \\
\text { code }\end{array}$ & $\begin{array}{l}\text { Latitude/ } \\
\text { longitude }\end{array}$ & $\begin{array}{l}\text { Altitude } \\
\text { (meters) }\end{array}$ & $\begin{array}{l}\text { Year of } \\
\text { fire }\end{array}$ & $\begin{array}{l}\text { Slope } \\
\left({ }^{\circ}\right)\end{array}$ & Aspect & Dominant species \\
\hline $\begin{array}{l}\text { Smokvica } \\
\text { B }\end{array}$ & $\begin{array}{l}42^{\circ} 55^{\prime} 25^{\prime \prime} \mathrm{N} \\
16^{\circ} 54^{\prime} 19^{\prime \prime} \mathrm{E}\end{array}$ & 82 & 2011 & 32 & $\mathrm{~N}$ & $\begin{array}{c}\text { Strawberry tree (Arbutus } \\
\text { unedo L), Holm oak } \\
\text { (Quercus ilex L.), Heather } \\
\text { (Calluna vulgaris L.) }\end{array}$ \\
\hline $\begin{array}{l}\text { Smokvica } \\
\mathrm{C}\end{array}$ & $\begin{array}{l}42^{\circ} 55^{\prime} 20^{\prime \prime} \mathrm{N} \\
16^{\circ} 54^{\prime} 18^{\prime \prime} \mathrm{E}\end{array}$ & 68 & & 28 & $S$ & $\begin{array}{c}\text { Black pine (Pinus nigra } \\
\text { J.F.Arnold), } \\
\text { Phillyrea (Phillyrea latifolia } \\
\text { L) }\end{array}$ \\
\hline Blato B & $\begin{array}{l}42^{\circ} 56^{\prime} 51 " \mathrm{~N} \\
16^{\circ} 50^{\prime} 25^{\prime \prime} \mathrm{E}\end{array}$ & 163 & 2012 & 39 & $\mathrm{~N}$ & $\begin{array}{l}\text { Different pines, Phillyrea } \\
(\text { Phillyrea latifolia } \mathrm{L})\end{array}$ \\
\hline Blato C & $\begin{array}{l}42^{\circ} 566^{\prime} 50^{\prime \prime} \mathrm{N} \\
16^{\circ} 50^{\prime} 21^{\prime \prime} \mathrm{E}\end{array}$ & 155 & & 42 & $\mathrm{~N}$ & $\begin{array}{l}\text { Aleppo pine (Pinus } \\
\text { halepensis Miller) }\end{array}$ \\
\hline Panjika B & $\begin{array}{l}42^{\circ} 51^{\prime} 19 " \mathrm{~N} \\
17^{\circ} 30^{\prime} 51^{\prime \prime} \mathrm{E}\end{array}$ & 310 & 2012 & 17 & $\mathrm{~W}$ & $\begin{array}{l}\text { Strawberry tree (Arbutus } \\
\text { unedo L), Holm Oak } \\
\text { (Quercus ilex L), maquis } \\
\text { (macchie), Prickly Juniper } \\
\text { (Juniperus oxycedrus L.) }\end{array}$ \\
\hline Panjika C & $\begin{array}{l}42^{\circ} 51^{\prime} 24^{\prime \prime} \mathrm{N} \\
17^{\circ} 30^{\prime} 25^{\prime \prime} \mathrm{E}\end{array}$ & 336 & & 25 & $\mathrm{~W}$ & $\begin{array}{l}\text { Different pines, Strawberry } \\
\text { tree (Arbutus unedo L.), }\end{array}$ \\
\hline
\end{tabular}




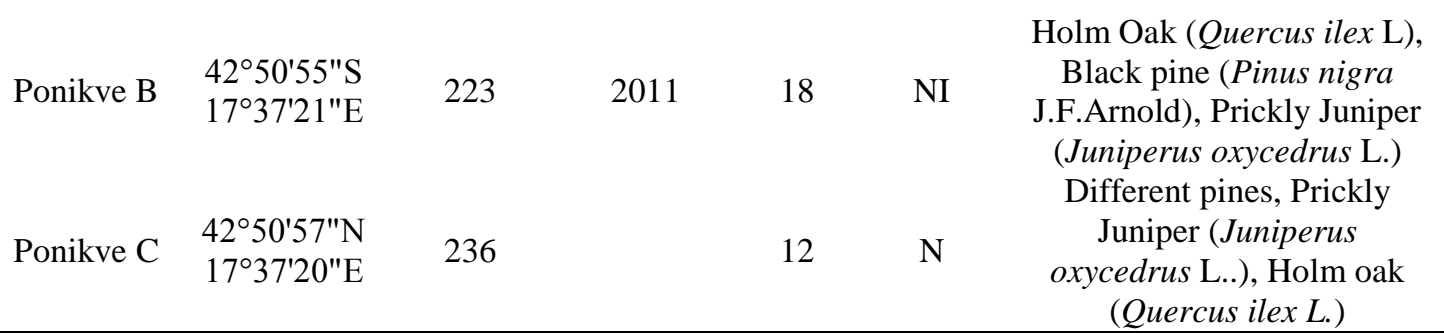

Survey areas consisted mainly of carbonate sedimentary rocks, limestones and dolomites. The karst bedrock in southern Dalmatia is dominantly covered by terra rossa - chromic cambisols (FAO, 2006), which cover the largest part of the coastal terrain and most of the islands. Most elevated areas in the highest mountain areas of the Peljesac peninsula are overlain by rendzic and mollic leptosols. Smaller patches on the island of Korcula are overlain by aric anthrosols.

\section{Plot Design and Soil Sampling}

At each site we collected 3 soil samples $(0-5 \mathrm{~cm})$ from burned and 3 from unburned plots (each taken sample consists of 10 individual samples homogenized into one) with similar aspect, slope, elevation and vegetation characteristics and those that have been diversely affected by wildfires in 2011 (areas burned 14 months prior to sampling) and 2012 (areas burned 2 months prior to sampling). The total number of collected samples is 24. Near each burned area unburned sample points were chosen according to their similarity to the burned areas in order to determine the differences between samples. Each composite sample was taken $40 \mathrm{~m}$ from another sample and represent an area of approximately $1200 \mathrm{~m}^{2}$. Samples were taken with spade and stored in plastic bags without air and taken to the laboratory for analysis.

\section{Preparation of Samples and Chemical Analysis}

In the laboratory prior to chemical analysis, the samples were air dried, milled and passed through a sieve of $2 \mathrm{~mm}$ diameter. The following soil properties were monitored in the $<2 \mathrm{~mm}$ fraction: soil $\mathrm{pH}, \mathrm{EC}$, plant available phosphorus $(\mathrm{P})$ and potassium $(\mathrm{K})$, $\mathrm{TC}, \mathrm{TN}, \mathrm{F}^{-}, \mathrm{Cl}^{-}, \mathrm{SO}_{4}{ }^{2-}, \mathrm{Na}^{+}, \mathrm{Mg}^{2+}$ and $\mathrm{Ca}^{2+}$. The soil $\mathrm{pH}$ was measured using the electrometric method in 1:2.5 (w/v) ratio with the Beckman $\mathrm{pH}$-meter $\Phi 72$, in $\mathrm{KCl}$ suspension (according to HRN ISO 11464:2004 norm). TN content was determined by dry combustion method according to HRN ISO 13878:1998. TC content was determined after dry combustion (HRN ISO 10694:1995). Plant available P and K were extracted by ammonium lactate (AL) solution (Egner et al., 1960) and detected by spectrophotometry and flame photometry, respectively. Electrical Conductivity was calculated at $25{ }^{\circ} \mathrm{C}$ on soil water (1:5) extract according to HRN ISO 11265:2004. Water-extractable anions $\left(\mathrm{F}^{-}, \mathrm{Cl}^{-}, \mathrm{SO}_{4}{ }^{2-}\right)$ and cations $\left(\mathrm{Na}^{+}, \mathrm{Ca}^{2+}, \mathrm{Mg}^{2+}\right)$ in soil samples were extracted in ultra-pure water in 1:10 (w/v) ratio according to ÖNORM L 1092 norm. After the extraction, samples were centrifuged, filtrated and contents of anions and cations were detected by suppressed conductivity on Doinex ICS-1000 system with an analytical column: for anions - Ion Pac AS $17(4 \times 250 \mathrm{~mm})$ and for cations - Ion Pac CS 16 (5x250 mm), all in compliance with HRN EN ISO 14911(2001) and HRN EN ISO 10304-1(1998). One-way ANOVA was carried out to test whether the investigated properties varied significantly amongst burned and unburned plots at each location. In 
case it did, the post-hoc Fisher test was applied to separate mean values at $\mathrm{P} \leq 0.05$. All statistical analyses were carried out with SAS Institute 9.1.3.

\section{Results}

Statistically significant differences were found in all chemical variables measured in soils that have been burned 14 and 2 months prior to sampling in contrast to unburned plots. Detailed results are presented in Figure 1 and Table 2.

TC concentrations were lower in the surface horizon of burned plots on Smokvica and Blato location, while burned plots on Panjika and Ponikve area recorded higher TC results. TC values ranged from $6.04 \%$ to $17.10 \%$ in burned samples, and from $6.82 \%$ to $13.07 \%$ in unburned samples. Mean value of TC was $10.19 \%$ in burned soils and $9.21 \%$ in unburned plots. Burned samples recorded higher value of TN in 3 of the 4 locations. The mean value of TN in burned samples was $0.55 \%$ and $0.37 \%$ in unburned samples. Burned plots contain higher amounts of TN than unburned and there was no significant difference only at Smokvica location.

The level of plant available $\mathrm{P}$ and $\mathrm{K}$ was significantly different among all locations. In unburned samples $\mathrm{P}$ ranged in very low supply levels (14 to $48 \mathrm{mg} \mathrm{kg}^{-1} \mathrm{P}_{2} \mathrm{O}_{5}$ ), while the burned samples had moderate to very rich $\mathrm{P}$ supply and values from 135 to $424 \mathrm{mg}$ $\mathrm{kg}^{-1} \mathrm{P}_{2} \mathrm{O}_{5}$, except for Blato location where $30 \mathrm{mg} \mathrm{kg}^{-1} \mathrm{P}_{2} \mathrm{O}_{5}$ were found. The average values of soil $\mathrm{K}$ supply were $737 \mathrm{mg} \mathrm{kg}^{-1} \mathrm{~K}_{2} \mathrm{O}$ in unburned samples and $425 \mathrm{mg} \mathrm{kg}^{-1}$ $\mathrm{K}_{2} \mathrm{O}$ in burned samples. These results show that the soil is very well supplied with $\mathrm{K}$, with the exception of unburned samples from Ponikve site.

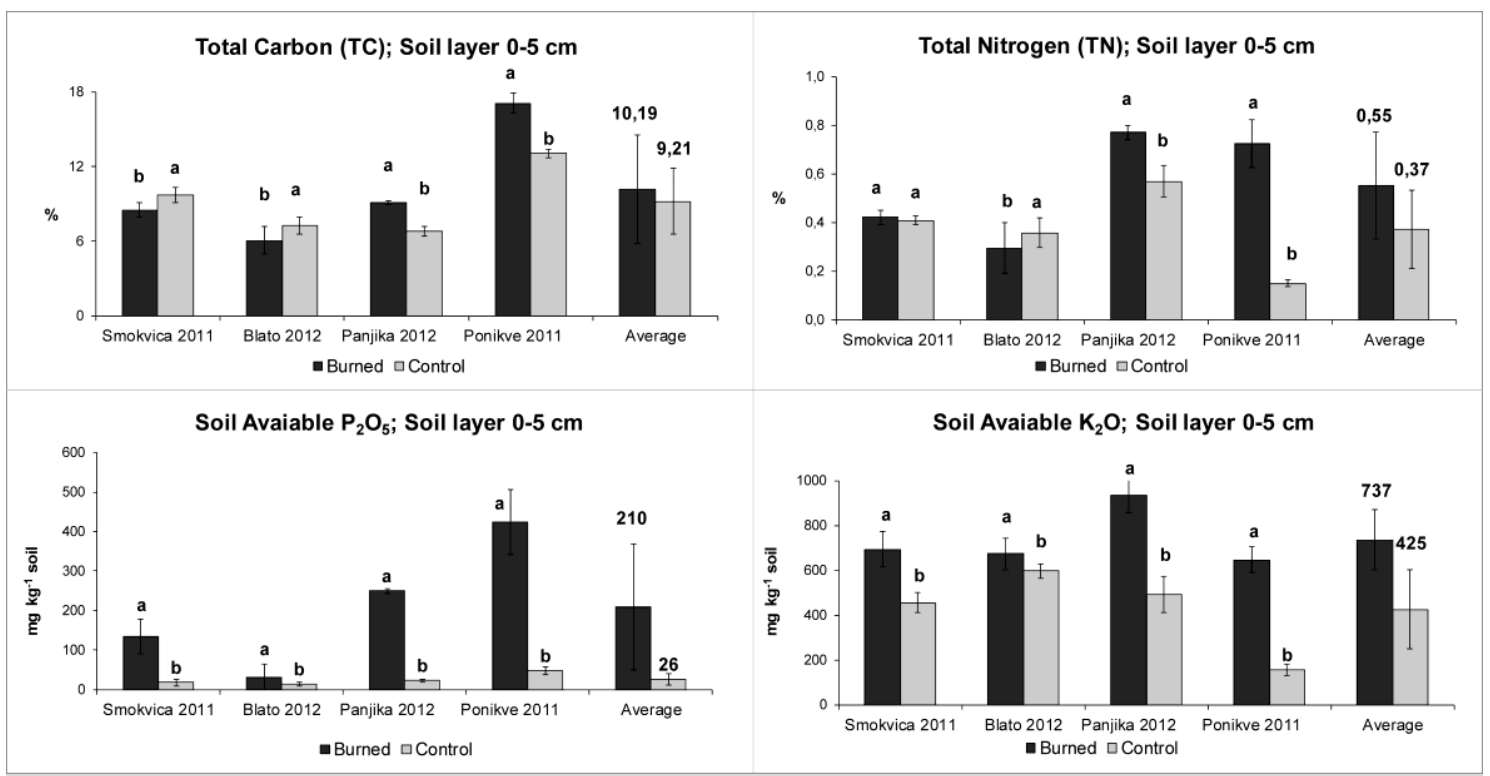

Figure 1. Mean values of soil chemical properties for burned and control plots. For each chemical property at each location bars with different lowercase letters are statistically different $(p<0.05)$. Hanging bars represent standard deviation.

Burned plots recorded neutral to alkaline $\mathrm{pH}$ which varied from 6.78 to 7.90 . The mean soil $\mathrm{pH}$ for unburned plots was 6.62, while unburned plots were low acid to neutral and their soil $\mathrm{pH}$ varied from 5.97 to 6.67 . Statistical differences between unburned and 
burned plots were observed in the $\mathrm{pH}$ in each location. In this study significant differences between burned and unburned samples were identified in $\mathrm{F}^{-}, \mathrm{SO}_{4}{ }^{2-}, \mathrm{Na}^{+}$, $\mathrm{Mg}^{2+}$ and $\mathrm{Ca}^{2+}$, in all investigated locations (Table 2). The amounts of $\mathrm{Ca}^{2+}, \mathrm{Mg}^{2+}, \mathrm{Na}^{+}$ and $\mathrm{SO}_{4}{ }^{2-}$ were significantly higher in burned plots than in unburned. Relatively high concentrations of $\mathrm{SO}_{4}{ }^{2-}, \mathrm{Na}^{+}, \mathrm{Mg}^{2+}, \mathrm{F}^{-}, \mathrm{Cl}^{-}$and $\mathrm{Ca}^{2+}$ were recorded in burned samples from all locations (with the exception of $\mathrm{Na}^{+}, \mathrm{F}^{-}$in Blato location). EC also showed significantly higher values in all four investigated sites, with almost $87 \%$ higher average value $\left(295.88 \mu \mathrm{S} \mathrm{cm}^{-1}\right)$ in burned than in unburned plots $\left(157.83 \mu \mathrm{S} \mathrm{cm}^{-1}\right)$.

Table 2. Mean concentration of $p H, E C$ and water-extractable elements in the burned (B) and unburned $(C)$ plots.

\begin{tabular}{|c|c|c|c|c|c|c|c|c|c|}
\hline \multirow{2}{*}{\multicolumn{2}{|c|}{ Sample code }} & $\mathrm{pH}$ & EC & $\mathbf{F}^{-}$ & $\mathrm{Cl}^{-}$ & $\mathrm{SO}_{4}{ }^{2-}$ & $\mathrm{Na}^{+}$ & $\mathrm{Mg}^{2+}$ & $\mathrm{Ca}^{2+}$ \\
\hline & & $-\log \left(\mathrm{H}^{+}\right)$ & $\mu \mathrm{S} \mathrm{cm}{ }^{-1}$ & \multicolumn{6}{|c|}{$\mathrm{mg} \mathrm{kg}^{-1}$} \\
\hline \multirow{2}{*}{$\begin{array}{c}\text { Smokvica } \\
2011\end{array}$} & B & $7.09 \pm 0.12 \mathrm{a}$ & $266.0 \pm 9.21 \mathrm{a}$ & $1.89 \pm 0.07 \mathrm{a}$ & $42.81 \pm 1.48 \mathrm{a}$ & $52.46 \pm 1.82 \mathrm{a}$ & $55.42 \pm 1.92 \mathrm{a}$ & $29.96 \pm 1.04 a$ & $542.79 \pm 18.80 \mathrm{a}$ \\
\hline & C & $6.20 \pm 0.17 \mathrm{~b}$ & $155.9 \pm 5.40 \mathrm{~b}$ & $0.39 \pm 0.01 \mathrm{~b}$ & $18.75 \pm 0.65 \mathrm{~b}$ & $21.91 \pm 0.76 \mathrm{~b}$ & $44.30 \pm 1.53 b$ & $6.92 \pm 0.24 \mathrm{~b}$ & $308.53 \pm 10.69 \mathrm{~b}$ \\
\hline \multirow{2}{*}{$\begin{array}{l}\text { Blato } \\
2012\end{array}$} & B & $6.78 \pm 0.05 a$ & $221.0 \pm 7.66 \mathrm{a}$ & $0.26 \pm 0.01 b$ & $47.88 \pm 1.66 \mathrm{a}$ & $65.97 \pm 2.29 \mathrm{a}$ & $57.19 \pm 1.98 \mathrm{~b}$ & $28.61 \pm 0.99 \mathrm{a}$ & $381.44 \pm 13.21 \mathrm{a}$ \\
\hline & $\mathrm{C}$ & $5.97 \pm 0.10 \mathrm{~b}$ & $146.5 \pm 5.07 \mathrm{~b}$ & $0.33 \pm 0.01 \mathrm{a}$ & $42.19 \pm 1.46 a$ & $28.89 \pm 1.00 \mathrm{~b}$ & $67.91 \pm 2.35 \mathrm{a}$ & $19.45 \pm 0.67 \mathrm{~b}$ & $245.64 \pm 8.51 \mathrm{~b}$ \\
\hline \multirow{2}{*}{$\begin{array}{c}\text { Panjika } \\
2012\end{array}$} & B & $7.31 \pm 0.03 \mathrm{a}$ & $335.5 \pm 11.26 \mathrm{a}$ & $4.29 \pm 0.05 \mathrm{a}$ & $104.33 \pm 7.41 \mathrm{a}$ & $327.66 \pm 8.21 \mathrm{a}$ & $57.17 \pm 2.51 \mathrm{a}$ & $27.30 \pm 2.17$ & $607.99 \pm 12.88 \mathrm{a}$ \\
\hline & C & $6.67 \pm 0.11 \mathrm{~b}$ & $173.5 \pm 8.26 \mathrm{~b}$ & $0.10 \pm 0.01 \mathrm{~b}$ & $22.12 \pm 1.22 \mathrm{~b}$ & $39.08 \pm 2.36 \mathrm{~b}$ & $42.13 \pm 1.32 \mathrm{~b}$ & $<0.01$ & $374.96 \pm 17.52 \mathrm{~b}$ \\
\hline \multirow{2}{*}{$\begin{array}{l}\text { Ponikve } \\
2011\end{array}$} & B & $7.90 \pm 0.04 a$ & $361.0 \pm 12.51 \mathrm{a}$ & $5.84 \pm 0.20 \mathrm{a}$ & $43.39 \pm 1.50 \mathrm{a}$ & $219.81 \pm 7.61 \mathrm{a}$ & $23.96 \pm 0.83 a$ & $175.56 \pm 6.08 \mathrm{a}$ & $447.59 \pm 15.51 \mathrm{a}$ \\
\hline & C & $6.62 \pm 0.02 b$ & $155.4 \pm 4.16 \mathrm{~b}$ & $0.33 \pm 0.08 b$ & $31.83 \pm 2.66 \mathrm{~b}$ & $34.55 \pm 0.66 \mathrm{~b}$ & $12.95 \pm 0.91 \mathrm{~b}$ & $46.79 \pm 2.55 b$ & $215.90 \pm 10.85 \mathrm{~b}$ \\
\hline \multirow{2}{*}{ Average } & B & $7.27 \pm 0.13$ & $295.91 \pm 17.29$ & $3.07 \pm 0.65$ & $59.60 \pm 7.98$ & $166.48 \pm 34.44$ & $48.43 \pm 4.34$ & $65.36 \pm 19.23$ & $494.95 \pm 26.99$ \\
\hline & C & $6.62 \pm 0.20$ & $157.8 \pm 3.89$ & $0.29 \pm 0.04$ & $28.72 \pm 2.85$ & $31.10 \pm 2.02$ & $41.82 \pm 5.92$ & $18.29 \pm 5.42$ & $286.26 \pm 19.18$ \\
\hline
\end{tabular}

* Values of standard error of mean are given after \pm . Different letters within a row for each location indicate significant differences $(\mathrm{p}<0.05)$.

\section{Discusion}

Carbon movement in the soil depends on fire severity (Pereira et al., 2010b), fire intensity, fire type (canopy or aboveground, underground fires), and even slope (González-Pérez et al., 2004). Low-intensity fires have little effect on the soil carbon while wildfires drastically reduce the amount of carbon in the soil (Johnson, 1992). Lower levels of carbon in burned samples one year after the fire in pine forests was recorded (Johnson, 1992), while other research (Binkley et al., 1992) observed lower amount of TC in burned soil than in unburned samples one and three years after the fire. Other studies recorded a nearly 50\% increase of soil carbon content in burned area than in unburned area (Rovira et al., 2012 ; Choromanska and DeLuca, 2002). Increases in soil carbon are also reported due to an increased deposition of dry leaves and charred plant materials in fires that affect the tree canopy (González-Pérez et al., 2004). Our findings also show contradictory results of $\mathrm{TC}$ on investigated locations. These differences could be explained with differences in vegetation characteristics between locations. Control plots on each location have different dominant species and therefore we can presume that recorded wildifers had an uneven amount of fuel for burning, different combustion process, such as air temperature and humidity, wind speed, and topography of the site. All these factors had an influence on fire severity and therefore 
on TC. Average values (all four locations) of TC between burned and unburned plots were small. These trends may be due to the lower temperatures and incomplete combustion of soil organic matter at Smokvica and Blato location. It is already noted that severity of wildfires strongly influence on soil organic matter. Fire does not necessarily reduce topsoil organic matter content in a significant manner and low intensity fires have even been reported to increase organic matter content (Varela et al., 2010). Furthermore, in time of sampling, 14 and 2 months after fire it is visible generally fast recovery on vegetation (Figure 2) in all locations, but especially at Blato and Smokvica location. We can presume that small differences in average values of TC between burned and unburned plots are consequence of fast organic matter recovery in burned plots which affects on $\mathrm{C}$ sequestration. It is also noted in others studies (Johnson and Curtis, 2001; Wang et al., 2012) that fire had little effect on soil carbon. Even though it is evident that burned areas record generally fast vegetation recovery, on Blato location burned plot recorded the lowest TC concentration compared to all other locations, likely due to erosion removing material from the soil surface. Furthermore, these different observations between locations may be attributed to differences in sampling time after fire, soil properties, vegetation differences between investigated locations and fire severity.

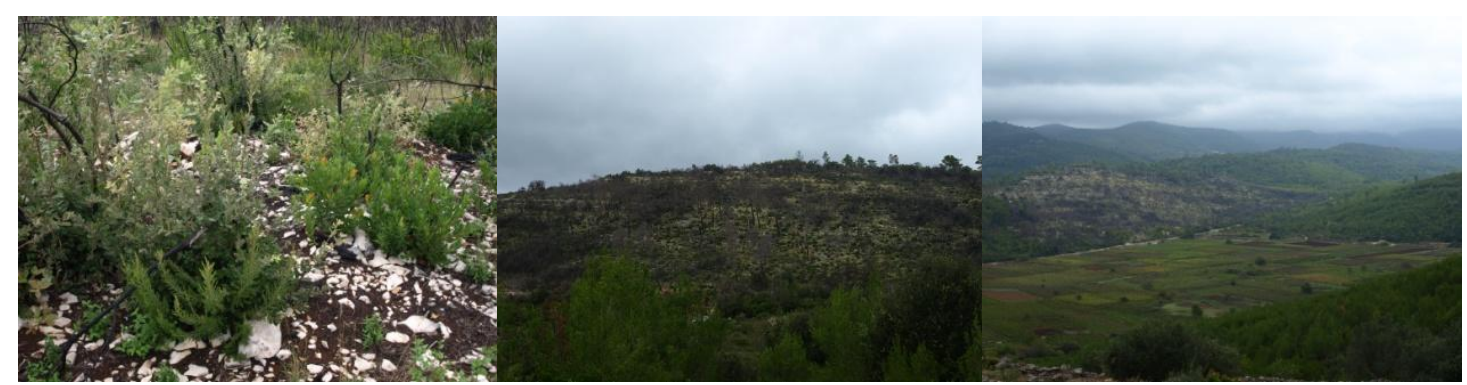

A)

B)

C)

Figure 2. From left to the right. Vegetation recovery on Blato $(A, B)$, and Smokvica $(C)$ location

Total nitrogen follow similar pattern on investigated locations like TC. Our results agree with previous studies carried out by Weston and Attiwill (1990), Rovira et al. (2012) and Choromanska and DeLuca (2002) who also observed differences in TN depending on fire severity and the time that has passed since the fire. Permanent study shows that fire can increase and decrease the amount of $\mathrm{N}$ in soil. Different study results are also reported in studies of Schoch and Binkley (1986) and Yinghua et al. (2012) who observed minimal $\mathrm{N}$ loss from a fire, but decomposition of the forest floor was stimulated by fire, releasing additional $\mathrm{N}$ during the following growing season, after the regeneration of vegetation. Results of $\mathrm{TN}$ in this study are different because $\mathrm{N}$ is soil after fire depends on many factors. Immediate after fire soil organic $\mathrm{N}$ is losing through volatilization (Binkley and Fisher, 2012), but some substantial portion of soil organic $\mathrm{N}$ can survive low intensity fires. Moderate to high intensity fires convert most soil organic $\mathrm{N}$ to inorganic forms. Ammonium is a consequence of the combustion, while nitrate forms are created from ammonium some weeks or months after fire as a result of nitrification (Covington and Sackett, 1992). These N-forms if are not taken by plants 
can leach (nitrate) or held by negatively charged minerals in soil (ammonium), thus affecting the overall result of TN in the soil.

It is generally expected that the $\mathrm{pH}$ increases in forests after the fire and decreases over time at the rate which it does so being dependent on precipitation (Woodmansee and Wallach, 1981). During wildfires the combustion of wood causes the mineralization of organic matter which increases the amount of basic elements, carbonates, oxides, hydroxides and base cations compounds that are rich in alkaline metals (Etiegni and Campbell, 1991; Ulery et al., 1993) that raise and explains the increase of soil $\mathrm{pH}$ and EC in our study. Furthermore, $\mathrm{pH}$ values increase as a result of oxidation of soil organic matter by combustion of some organic acids (Certini, 2005), and EC increase as result of release of inorganic ions from combusted organic matter (Hernandez et al., 1997). Also, topsoil $\mathrm{pH}$ could increase as much as three units immediately after burning (Ulery et al., 1993). This rise was essentially due to the production of $\mathrm{K}$ and $\mathrm{Na}$ oxides, hydroxides, and carbonates, which did not persist through the rainy season in contrast to neo-formed calcite that was still present 3 years after burning, and maintained moderately alkaline soil $\mathrm{pH}$. It is estimated that capacity of ash to neutralize soil acidity is well correlated with the sum of the concentrations of $\mathrm{K}^{+}, \mathrm{Ca}^{2+}$, and $\mathrm{Mg}^{2+}$ in the ash itself (Khanna et al., 1994). Except ash extracts that are rich in K (Badía and Martí, 2003; Ùbeda et al., 2009) higher noted levels of soil K supply were also result of natural content for terra rosa. $\mathrm{Ca}^{2+}$ also comes from limestone which is parent material on investigated areas. After fire, precipitation trough leaching and erosion move nutrient rich materials, washes away basics elements which finally leads to a decrease in $\mathrm{pH}$ during time. Even though the research areas were in the zones of mixed vegetation, forests, and low vegetation, the obtained results confirmed the above assertion. Investigated areas have an uneven precipitation distribution which is reflected in the long spring-summer dry season and rainy winters, and further research should provide insight into the time needed for the soil $\mathrm{pH}$ decreasing to pre-fire levels.

Average $\mathrm{P}$ supply value was eight times higher in burned samples than in unburned samples, as shown in other study (Yinghua et al., 2012). Some studies found no differences between burned and unburned samples (Binkley et al., 1992) and others (McKee, 1982) recorded significantly higher amounts of $\mathrm{P}$ in burned soil. These differences in burned and unburned soil are result of soil $\mathrm{pH}$ and fire. After fire, $\mathrm{P}$ in ash can leach into run-off and into the soil profile and may have impacts on surface chemistry. Burning converts the organic pool of soil phosphorus to orthophosphate (Cade-Menun et al., 2000), the sole form of $\mathrm{P}$ available to biota. The maximum $\mathrm{P}$ bioavailability values were recorded at $\mathrm{pH}$ of about 6.5 (Sharpely, 2000). But generally, fire-induced change in soil $\mathrm{pH}$ toward neutrality has a positive effect on $\mathrm{P}$ bioavailability, as shown in this study. Our results recorded higher $\mathrm{pH}$ values in burned plot than in unburned which directly affects on correlation with measured higher $\mathrm{P}$ values in burned plots in contrast to the unburned.In our work, we observed that all water-extractable base cations were significantly higher in burned soil compared with unburned soil solutions. Water extractable elements concentrations in burned plots are result of higher soil EC as a consequence of nutrient rich ash material on surface. Furtermore, fire suppression by seawater are reason for aditional source of $\mathrm{Na}^{+}, \mathrm{Mg}^{2+}$, $\mathrm{Ca}^{2+}, \mathrm{K}^{+}, \mathrm{Cl}^{-}$which explains the higher values of these ions in burned soil compared to unburned soil solution. Increased concentrations of soluble elements helps increased alkalinity of burned soils. There are a number of factors that influence the vulnerability of sites to total salt accumulation (Oster et al., 1996). These factors include the position 
of a site within a landscape (Manning et al., 2001), soil type and rainfall. Soil type was the same - terra rossa, in all four investigated locations. Average annual precipitation rate was relatively high with $1300 \mathrm{~mm}$ (Meteorological and hydrological institute of Croatia), but with extremes in distribution, because almost $80 \%$ of rain falls in a period from September through May. The rain did not reduce the amount of salt in the soil, not even in locations that burned two years ago. Although, this depends of several factors as rainfall intensity, topography, vegetation cover etc. Our results show that time that has passed after the fire didn't have effects on salt accumulation in investigated locations. At all sites burned plots recorded higher total salts (EC) values compared to control although the sites burned in 2011 had one more rainy season. Also, the magnitude of salt accumulation in a single growth season is often small and may not be readily detectable by the routine soil sampling in the field (Chen et al., 2010). However, it should be noted that data of the size and intensity of rainfall at each investigated location were not available, so it is based on assumption. Thus, further research should clarify this situation. It remains to been seen how many years it will take for the soil that was treated with seawater to return to pre-burned conditions. In future research will be interesting to observe separated influence of seawater on burned soil properties compared to burn soil suppressed by freshwater on soil.

\section{Conclusions}

This study was conducted in southern Dalmatia fire-sensitive coniferous forests of pine trees with maquis and it shows that there is a difference in terms of soil properties between areas burned by wildfires suppressed by seawater and similar areas that remained unburned. The results show a difference in almost all investigated soil properties. Higher values of P, K, TN and TC have been recorded in burned plots. After the fire soil $\mathrm{pH}, \mathrm{EC}$ and extractable cations and anions increase and this is attributed to the effect of ash and salt water used for suppression. Soil $\mathrm{pH}$ conditions after wildfire favors the solubility of some elements presented in this paper. This study cannot separate effect of seawater and fire influence on soil chemistry. The fact that the fire is extinguished with seawater may have implications on soil chemistry in the post fire period, but this can be clearer in a long-term study that compares burned soils extinguished with seawater and fresh water. This study is useful for understanding changes in soil chemistry after fire and seawater application. However, further studies with better establish experiment that includes divided causes on soil, fire and salt water, and continuous monitoring of soil changes is needed.

\section{REFERENCES}

[1] Ahmed, O., Inoue, M., Moritani, S. (2010): Effect of saline water irrigation and manure application on the available water content, soil salinity, and growth of wheat. Agricultural Water Management 97(1): 165-170.

[2] Andreu, V., Rubio, J.L., Forteza, J., Cerni, R. (1996): Postfire Effects on Soil Properties and Nutrient Losses. - International Journal of Wildland Fire 6(2): 53-58.

[3] Badía, D., Martí, C. (2003): Plant ash and heat intensive effects on chemical and physical properties of two contrasting soils. - Arid Land Research and Management 17: 23-41.

[4] Ben Ahmed, C., Magdich, S., Ben Rouina, B., Boukhris, M., Ben Abdullah, F. (2012): Saline water irrigation effects on soil salinity distribution and some physiological 
responses of field grown Chemlali olive. Journal of environmental management 113: 538544.

[5] Binkley, D., Fisher, R. (2012): Ecology and management of forest soils. - John Wiley \& Sons, New York, USA 2012.

[6] Binkley, D., Richter, D., David, M.B., Caldwell, B. (1992): Soil chemistry in a loblolly/longleaf pine forest with interval burning. - Ecological Applications 2(2): 157164.

[7] Bogunovic, I., Kisic, I., Jurisic, A. (2014): Impact of fire on the chemical characteristics of the soil in the Dalmatia. - In: Samardzija, Lj. (ed.). First online conference on forest and agricultural fires as one of the important causes of climate change. Udruženje: Čovjek i prirodni resursi, Bihać, Bosnia and Herzegovina.

[8] Cade-Menun, B.J., Berch, S.M., Preston, C.M., Lavkulich, L.M. (2000): Phosphorus forms and related soil chemistry of Podzolic soils on northern Vancouver Island. II. The effects of clear-cutting and burning. - Canadian Journal of Forest Research 30(11): 17261741.

[9] Cammeraat, L.H., Imeson, A.C. (1999): The evolution and significance of soil-vegetation patterns following land abandonment and fire in Spain, the significance of soil, water and landscape processes in banded vegetation patterning. - Catena 37(1-2): 107-127.

[10] Cerdà, A. (1998a): Postfire dynamics of erosional processes under Mediterranean climatic conditions. - Zeitschrift fur Geomorphologie 42(3): 373-398.

[11] Cerdà, A. (1998b): Changes in overland flow and infiltration after a rangeland fire in a Mediterranean scrubland. - Hydrological Processes 12: 1031-1042.

[12] Cerdà, A., Doerr, S.H. (2008): The effect of ash and needle cover on surface runoff and erosion in the immediate post-fire period. - Catena 74(3):256-263.

[13] Certini, G. (2005): Effects of fire on properties of forest soils: a review. - Oecologia 143(1): 1-10.

[14] Certini, G., Nocentini, C., Knicker, H., Arfaioli, P., Rumpel, C. (2011): Wildfire effects on soil organic matter quantity and quality in two fire-prone Mediterranean pine forests. Geoderma 167:148-155.

[15] Chen, W., Hou, Z., Wu, L., Liang, Y., Wei, C. (2010): Evaluating salinity distribution in soil irrigated with saline water in arid regions of northwest China. - Agricultural Water Management 97(12):2001-2008.

[16] Choromanska, U., DeLuca, T.H. (2002): Microbial activity and nitrogen mineralization in forest mineral soils following heating: evaluation of post-fire effects. - Soil Biology and Biochemistry 34(2): 263-271.

[17] Covington, W.W., Sackett, S.S. (1992): Soil mineral nitrogen changes following prescribed burning in ponderosa pine. - Forest Ecology Management 54(1): 175-191.

[18] Dlapa, P., Bodí, M.B., Mataix-Solera, J., Cerdà, A., Doerr, S.H. (2013): FT-IR spectroscopy reveals that ash water repellency is highly dependent on ash chemical composition. - Catena 108:35-43.

[19] Egner, H., Riehm, H., Domingo, W.R. (1960): Untersuchungen über die chemische Bodenanalyse als Grundlage für die Beurteilung des Nährstoffzustandes der Böden. II Chemische Extraktionsmethoden zur Phosphor und Kalium. - Kungliga Lantbrukshögskolans Annaler 26:45-61. (In German).

[20] Etiegni, L., Campbell, A.G. (1991): Physical and chemical characteristics of wood ash. Bioresource Technology 37:173-178.

[21] FAO (2006): World reference base for soil resources. A framework for international classification and communication, $103 \mathrm{p}$.

[22] González-Pérez, J.A., González-Vila, F.J., Almendros, G., Knicker, H. (2004): The effect of fire on soil organic matter-a review. - Environment International 30(6): 855-870.

[23] Hatten, J., Zabowski, D., Scherer, G., Dolan, E. (2005): A comparison of soil properties after contemporary wildfire and fire suppression. - Forest Ecology Management 220: 227-241. 
[24] Hernandez, T., Garcia, C., Reinhardt, I. (1997): Short-term effect of wildfire on the chemical, biochemical and microbiological properties of Mediterranean pine forest soils. - Biology and Fertility of Soils 25(2): 109-116.

[25] HRN ISO 10694 (1995): Soil quality - Determination of organic and total carbon after dry combustion. Croatian Standards Institute, Zagreb.

[26] HRN ISO 13878 (1998): Soil quality - Determination of total nitrogen content by dry combustion. Croatian Standards Institute, Zagreb.

[27] HRN ISO 10304-1 (1998): Water quality - Determination of dissolved anions by liquid chromatography of ions - Part 1: Determination of bromide, chloride, fluoride, nitrate, nitrite, phosphate and sulfate. Croatian Standards Institute, Zagreb.

[28] HRN ISO 14911 (2001): Water quality - Determination of dissolved Li+, Na+, NH4+, $\mathrm{K}+, \mathrm{Mn} 2+, \mathrm{Ca} 2+, \mathrm{Mg} 2+, \mathrm{Sr} 2+\mathrm{i} \mathrm{Ba} 2+$ using ion chromatography - Method for water and waste water. Croatian Standards Institute, Zagreb.

[29] HRN ISO 11265 (2004): Soil quality - Determination of the specific electrical conductivity. Croatian Standards Institute, Zagreb.

[30] HRN ISO 11464 (2004): Soil quality - Determination of pH. Croatian Standards Institute, Zagreb.Johnson, D.W. (1992): Effects of forest management on soil carbon storage. Water Air and Soil Pollution 64(1-2): 83-120.

[31] Johnson, D.W., Curtis, P.S. (2001): Effects of forest management on soil C and N storage: meta analysis. - Forest Ecology Management 140: 227-238.

[32] Juan, P., Mateu, J., Jordan, M.M., Mataix-Solera, J., Meléndez-Pastor, I., NavarroPedreno, J. (2011): Geostatistical methods to identify and map spatial variations of soil salinity. - Journal of Geochemical Exploration 108(1): 62-72.

[33] Katerji, N., Van Hoorn, J.W., Hamdy, A., Mastrorilli, M. (2003): Salinity effect on crop development and yield, analysis of salt tolerance according to several classification methods. - Agricultural Water Management 62(1): 37-66.

[34] Khanna, P.K., Raison, R.J., Falkiner, R.A. (1994): Chemical properties of ash derived from Eucalyptus litter and its effects on forest soils. - Forest Ecology Management 66(1): 107-125.

[35] Liodakis, S., Katsigiannis, G., Kakali, G. (2005): Ash properties of some dominant Greek forest species. - Thermochimica Acta 437:158-167.

[36] Liodakis, S., Katsigiannis, G., Lymperopoulou, T. (2007): Ash properties of Pinus halepensis needles with diammonium phosphate. - Thermochimica Acta 453(2): 136-146.

[37] Mamut, M. (2011): Ties between the Geographical and Social Geographical Features of Dalmatia with the Endangerment of Forest Fires. - Journal of Forestry 1-2: 37-50.

[38] Manning, G., Fuller, L.G., Eilers, R.G., Florinsky, I. (2001): Topographic influence on the variability of soil properties within an undulating Manitoba landscape. - Canadian Journal of Soil Science 81(4): 439-447.

[39] Martinac, V. (2010): Magnesium oxide from seawater. - University handbook, Faculty of Chemistry and Technology, Split, Croatia, $110 \mathrm{p}$.

[40] Martínez-Sánchez, J.J., Ferrandis, P., de las Heras, J., Herranz, J.M. (1999): Effect of burnt wood removal on the natural regeneration of Pinus halepensis after fire in a pine forest in Tus valley (SE Spain). - Forest Ecology Management 123(1): 1-10.

[41] Mataix-Solera, J., Cerdà, A. (2009): Incendios forestales en España. Ecosistemas terrestres y suelos. - In: Cerdà, A. and Mataix-Solera, J. (eds.). Efectosde los incendios forestales sobre los suelos en España, Catedra de Divulgación de la Ciencia, Universitat de València, València, pp. 27-53.

[42] McKee, W.H. (1982): Changes in soil fertility following prescribed burning on Coastal Plain pine sites. - US Department of Agriculture, Southeastern Forest Experiment Station, Forest Service. p.23.

[43] Monleon, V.J., Cromack, Jr.K., Landsberg, J.D. (1997): Short- and long-term effects of prescribed underburning on nitrogen availability in ponderosa pine stands in central Oregon. - Canadian Journal of Forest Research 27:369-378. 
[44] Navarro-Pedreño, J., Moral, R., Gómez, I., Almendro, M.B., Palacios, G., Mataix, J. (1997): Saline soils due to saltworks: salt flats in Alicante. - In: Battle-Sales, J. (ed). Proceedings International Symposium on Salt-Affected Lagoon Ecosystems, 1997 September 18-25, Valencia, Spain, p. 437-440.

[45] Oster, J.D., Shainberg, I., Abrol, I.P. (1996). Reclamation of salt-affected soil. - In: Agassi, M. (ed.). Soil Erosion, Conservation and Rehabilitation. Marcel Dekker, New York, p. 315-351.

[46] Pereira, P., Úbeda, X., Mataix-Solera, J., Cerdà, A. (2010a): Forest management using prescribed fires: Opportunities and barriers. - Darnaus vysymosi strategija ir praktika 1(4): 81-95.

[47] Pereira, P., Bodí, M.B., Úbeda, X., Cerdà, A., Solera, J.M., Balfour, V., Woods, S. (2010b): Las cenizas en el ecosistema suelo. - In: Cerdà, A. and Jorán, A. (eds.). Actualización en métodos y técnicas para el estudio de los suelos afectados por incendios forestales,. Cátedra Divulgación de la Ciencia, Universitat de València, València, p. 349401.

[48] Pereira, P., Cerdà, A., Úbeda, X., Mataix-Solera, J., Arcenegui, V., Zavala, L.M. (2013): Modelling the impacts of wildfire on ash thickness in a short-term period. - Land Degradatio and Development.

[49] Pereira, P., Mierauskas, P., Ubeda, X., Mataix-Solera, J., Cerda, A. (2012): Fire in Protected Areas-the Effect of Protection and Importance of Fire Management. Environmental Research, Engineering and Management 59(1): 52-62.

[50] Pereira, P., Úbeda, X., Martin, D., Mataix-Solera, J., Guerrero, C. (2011): Effects of a low severity prescribed fire on water-soluble elements in ash from a Cork Oak (Quercus suber) forest located in the Northeast of the Iberian Peninsula. - Environmental Research 111: 237-247.

[51] Richards, R.A. (1992): Increasing salinity tolerance of grain crops: Is it worthwhile? Plant and Soil 146(1-2): 89-98.

[52] Rovira, P., Romanyà, J., Duguy, B. (2012): Long-term effects of wildfires on the biochemical quality of soil organic matter: A study on Mediterranean shrublands. Geoderma 179: 9-19.

[53] Schoch, P., Binkley, D. (1986): Prescribed burning increased nitrogen availability in a mature loblolly pine stand. - Forest Ecology Management 14(1): 13-22.

[54] Shalhevet, J. (1993): Plants under water and salt stress. - In: Fowden L. et al. (eds.). Plant adaptation to environmental stress. Chapman and Hall, New York, USA. p. 133-154.

[55] Sharpley, A. (2000): Phosphorus availability. - In: Sumner, M.E. (ed.). Handbook of soil science. CRC, Boca Raton, Fla. D18- D38.

[56] Sheng, F., Xiuling, C. (1997): Using shallow saline groundwater for irrigation and regulating for soil salt-water regime. - Irrigation and Drainage Systems 11(1): 1-14.

[57] Úbeda, X., Pereira, P., Outeiro, L., Martin, D. (2009): Effects of fire temperature on the physical and chemical characteristics of the ash from two plots of cork oak (Quercus suber). - Land Degradation and Development 20: 589-608.

[58] Ulery, A.L., Graham, R.C., Amrhein, C. (1993): Wood-ash composition and soil pH following intense burning. - Soil Science 156(5): 358-364.

[59] Varela, M.E., Benito, E., Keizer, J.J. (2010): Effects of wildfire and laboratory heating on soil aggregate stability of pine forests in Galicia: The role of lithology, soil organic matter content and water repellency. - Catena 83(2): 127-134.

[60] Wang, Q., Zhong, M., Wang, S. (2012): A meta-analysis on the response of microbial biomass, dissolved organic matter, respiration, and $\mathrm{N}$ mineralization in mineral soil to fire in forest ecosystems. -Forest Ecology and Management 271: 91-97.

[61] Weston, C.J., Attiwill, P.M. (1990): Effects of fire and harvesting on nitrogen transformations and ionic mobility in soils of Eucalyptus regnans forests of south-eastern Australia. - Oecologia 83(1): 20-26. 
[62] Woodmansee, R.G., Wallach, L.S. (1981): Effects of fire regimes on biogeochemical cycles. In: Clark, F.E. and Rosswall, T. (eds.). Terrestrial Nitrogen Cycles. - Ecological Bulletin 33: 649-669.

[63] Yinghua, X., Jian, S., Qing, L., Jing, M., Yingwu, S., Kai, L. (2012): Effects of a surface wildfire on soil nutrient and microbial functional diversity in a shrubbery. - Acta Ecologica Sinica 32(5): 258-264. 